\title{
Analisis Rasio Profitabilitas PT. Bank Perkreditan Rakyat Batang Kapas
}

\author{
Endah Sundari'), Doni Marlius ${ }^{2)}$ \\ 1.2) Akademi Keuangan dan Perbankan "Pembangunan" Padang \\ endahsundari919@gamail.com
}

\begin{abstract}
This research was conducted to find out how the level of profitability by using the ratio of ROA (Return on Asset), ROE (Return on Equity), BOPO (Operating Expenses to Operating Income), and NPM (Net Profit Margin) to PT. BPR Batang Kapas. The type of data used is secondary data obtained by the documentation method taken from the PT.BPR Batang Kapas publication report during the period 2017-2019. This research was conducted using the 2017-2019 financial statements, namely the balance sheet and income statement. The results of this study indicate that the bank ROA level is in a very good position with the ROA criteria $>1.5 \%$. The ROE level also shows that the bank position is in a fairly good condition with the criteria of $13 \%<R O E \leq 18 \%$ so that the bank ability to generate net profit is still not good. In the BOPO position the bank shows a fairly good condition with the criteria of $85 \%<B O P O \leq 87 \%$. While the NPM is in a position which indicate that the condition of the bank has decreased with the criteria of $<51 \%$, which means the bank is said to be bad and has not been able to generate net profit.
\end{abstract}

Keyword: Return on Asset (ROA), Return on Equity (ROE), Net Profit Margin $(N P M), B O P O$,

\section{PENDAHULUAN}

Kondisi pandemi covid-19 saat ini turut menekan perekonomian nasional maupun global, khususnya perbankan juga ikut terdampak. Ada dua hal penting yang bisa dilakukan perbankan untuk bertahan dalam kondisi sulit seperti saat ini yaitu dengan mengelola arus kas dan laba rugi. Namun dalam kondisi ini masih banyak aspek yang dibenahi dalam pengawasan perbankan.

Meskipun saat ini secara keseluruhan manajemen resiko dan pengawasan berjalan dengan masih cukup baik. Kondisi perbankan saat ini masih stabil yang ditunjukkan oleh kondisi permodalan dan likuiditas yang memadai serta profil resiko yang terjaga.

Dalam undang-undang No. 10 tahun 1998 tentang perbankan, menurut jenisnya bank terdiri dari Bank Umum dan Bank Perkreditan Rakyat (BPR). Bank Perkreditan Rakyat adalah bank yang melaksanakan kegiatan usaha secara konvensional atau berdasarkan prinsip syariah yang dalam kegiatannya tidak memberikan jasa lalu lintas pembayaran.

Laporan keuangan yaitu gambaran kondisi keuangan dan hasil usaha suatu bank atau perusahaan pada saat tertentu atau jangka waktu yang telah ditentukan. Dalam kegiatan sehari-hari bank tidak terlepas dari bidang keuangan, baik dalam 
menganalisa dan menilai posisi keuangan untuk mengetahui seberapa jauh kemampuan bank dalam menghasilkan keuntungan. Maka untuk mengukur keefektifan kagiatan operasional bank dapat diketahui melalui rasio profitabilitas.

Bank yang sehat dapat dikatakan bahwa bank yang menjalankan fungsinya dengan baik, menjaga kepercayaan masyarakat, menjalankan fungsi intermediasi, dan dapat memperlancar lalu lintas pembayaran. Dalam hal tersebut suatu bank dapat meningkatkan keuntungan perusahaan, karena laba sangat mempengaruhi kondisi bank, apakah bisa bertahan atau tidak.

\section{Tabel 1}

Data keuangan rasio profitabilitas

PT. BPR Batang kapas Periode 2017-2019

(Dalam Rupiah)

\begin{tabular}{cccc}
\hline Keterangan & Tahun 2017 & Tahun 2018 & Tahun 2019 \\
\hline Total aset & 32.528 .837 .413 & 34.923 .792 .170 & $\begin{array}{c}36.364 .957 .2 \\
83\end{array}$ \\
Modal sendiri & 4.005 .000 .000 & 4.754 .000 .000 & $\begin{array}{c}5.177 .000 .00 \\
0\end{array}$ \\
Pendapatan & 4.783 .915 .970 & 4.899 .310 .576 & $\begin{array}{c}5.414 .570 .91 \\
7\end{array}$ \\
$\begin{array}{c}\text { operasional } \\
\text { Beban operasional }\end{array}$ & 4.071 .682 .374 & 4.175 .073 .712 & 4.655 .176 .74 \\
& & & 8 \\
Laba sebelum & 707.538 .597 & 715.387 .865 & 754.153 .671 \\
pajak & & & \\
Laba bersih & 659.699 .437 & 670.644 .872 & 649.184 .546 \\
\hline
\end{tabular}

Sumber : Laporan Keuangan PT. BPR Batang Kapas

Berdasarkan tabel 1 diatas dapat dilihat bahwa PT BPR Batang kapas

dalam neraca dan laporan laba rugi perusahaannya masih berfluktuasi. Hal ini dapat diketahui dari perolehan pendapatan pada tahun 2017 (4.783.915.970), tahun 2018 (4.899.310.576) dan tahun 2019 mengalami kenaikan sebesar (5.414.570.917).

Sedangkan untuk perolehan laba bersih pada tahun 2017 (659.699.437), tahun 2018 (670.644.872) mengalami kanaikan, dan tahun 2019 mengalami penurunan sebesar (649.184.546).

\section{METODE PENELITIAN}

Dalam pengumpulan data dan bahan untuk penelitian ini digunakan metode penelitian sebagai berikut: a. Riset lapangan (Field Research) yaitu peninjauan langsung ke objek penelitian yang dipilih untuk meneliti hasil data sekunder. Penelitian langsung kelapangan ini akan dapat membantu penulis untuk melengkapi data yang diperlukan. Adapun cara riset lapangan ini adalah dengan mewawancarai langsung pihak-pihak yang berkepentingan dalam hal ini adalah perusahaan dan instansi yang terkait. b. Riset kepustakaan (Library Research) yaitu penelitian yang dilakukan keperpustakaan beberapa buku-buku ilmiah dan tulisan-tulisan yang berhubungan dengan pembahasan yang dilakukan. 


\section{HASIL DAN PEMBAHASAN}

1. Rasio Return On Assets (ROA)

Return on assets adalah rasio yang menggambarkan tingkat keuntungan (earning) yang didapatkan oleh manajemen atas total aset yang dimiliki.

Return on assets adalah rasio yang mencerminkan kesanggupan bank dalam mengendalikan dana yang diinvestasikan dalam semua aset yang mendatangkan keuangan (Sari \& Marlius, 2019). Rasio ini dipakai oleh bank untuk mengukur kesanggupan manajemen Bank Perkreditan Rakyat dalam mendapatkan keuntungan atau laba secara keseluruhan. Serta rasio ini juga dapat menggambarkan efisiensi kemampuan kerja bank dalam mengelola seluruh biaya-biaya operasional dan non-operasional. Matriks kriteria penilaian tingkat ROA sebagai berikut :

ROA $>1,5 \%$ Sangat baik

$1,25 \%<\mathrm{ROA} \leq 1,5 \%$ Baik

$0,5 \%<\mathrm{ROA} \leq 1,25 \%$ Cukup

$0 \%<$ ROA $\leq 0,5 \%$ Tidak baik

ROA $\leq 0 \%$ Sangat tidak baik

Berdasarkan data yang diperoleh Return On Assets PT. BPR Batang Kapas pada tahun 2017 sampai 2019 ditunjukkan pada tabel dibawah ini :

Tabel 2

Perhitungan Return On Assets PT. BPR Batang Kapas

Tahun 2017-2019 (Dalam Rupiah)

\begin{tabular}{|c|c|c|c|}
\hline Komponen & Tahun 2017 & Tahun 2018 & Tahun 2019 \\
\hline 1. Return On & & & \\
\hline Assets & & & \\
\hline $\begin{array}{l}\text { a. Laba sebelum } \\
\text { pajak }\end{array}$ & 707.538 .597 & 715.387 .865 & 754.153 .671 \\
\hline b. Total aset & 32.528 .837 .413 & 34.923 .792 .170 & 36.364 .957 .283 \\
\hline
\end{tabular}

Sumber : Laporan Keuangan PT. BPR Batang Kapas

Laba Sebelum Pajak

Dengan formula : ROA $=-\times 100 \%$

Total Aset

1. Tahun 2017

$$
\begin{aligned}
\text { ROA } & =\frac{707.538 .597}{32.528 .837 .413} \times 100 \% \\
& =2,17 \%
\end{aligned}
$$

2. Tahun 2018

$$
\begin{aligned}
\text { ROA } & =\frac{715.387 .865}{34.923 .792 .170} \times 100 \% \\
& =2,04 \%
\end{aligned}
$$


3. Tahun 2019

$$
\begin{aligned}
\text { ROA } & =\frac{754.153 .671}{36.364 .957 .283} \times 100 \% \\
& =1,19 \%
\end{aligned}
$$

Dari ROA PT. BPR Batang Kapas dapat disimpulkan bahwa tahun 2017 sebesar 2.17\%, tahun 2018 sebesar $2.04 \%$ dan pada tahun 2019 sebesar $1.19 \%$. Berdasarkan perhitungan tersebut dapat disimpulkan ROA PT. BPR Batang Kapas mengalami penurunan. Tetapi walaupun mengalami penurunan keterangan nya adalah baik. Sebab perusahaan bisa memanfaatkan asset dengan baik sehingga menimbulkan keuntungan pada perusahaan. Perusahaan dapat memanfaatkan aset dengan baik dan efisien sehingga menghasilkan ROA yang tinggi pula. Jika perusahaan terus mengalami kenaikan ROA tiap tahunnya maka pendapatan perusahaan akan meningkat sehingga kreditur dan investor akan bertambah karena peningkatan yang baik pada pendapatan perusahaan.

2. Rasio Return On Equity (ROE)

Menurut (Oktaviani, 2015) Return On Equity menunjukkan besarnya pengembalian atas investasi pemegang saham biasa. Dalam rasio ini menerangkan daya untuk mendapatkan laba atas investasi berdasarkan nilai buku para pemegang saham. Matriks penilaian tingkat rasio ROE menurut Bank Indonesia (Surat Edaran Bank Indonesia, 2004) adalah sebagai berikut :

ROE $>23 \%$ Sangat baik

$18 \%<\mathrm{ROE} \leq 23 \%$ Baik

$13 \%<$ ROE $\leq 18 \%$ Cukup

$8 \%<$ ROE $\leq 13 \%$ Tidak baik

$\mathrm{ROE} \leq 8 \%$ Sangat tidak baik

Berdasarkan data yang diperoleh Return On Equity PT. BPR Batang Kapas pada periode 2017 sampai 2019 ditunjukkan pada tabel dibawah ini :

\section{Tabel 3}

Perhitungan Return On Equity PT. BPR Batang Kapas Tahun 2017-2019

(Dalam Rupiah)

\begin{tabular}{lccc}
\hline \multicolumn{1}{c}{ Komponen } & Tahun 2017 & Tahun 2018 & Tahun 2019 \\
\hline 1. Return On Equity & & & \\
a. Laba bersih setelah pajak & 659.699 .437 & 670.644 .872 & 649.184546 \\
b. Modal sendiri & 4.055 .000 .000 & 4.754 .000 .000 & 5.177 .000 .000 \\
\hline
\end{tabular}

Sumber : Laporan Keuangan PT. BPR Batang Kapas

Laba Bersih Setelah Pajak

Dengan formula : ROE =

$$
\text { Laba Bersih Setelah Pajak }
$$

1. Tahun 2017

Modal Sendiri

$$
\begin{aligned}
\mathrm{ROE} & =\frac{659.699 .437}{4.055 .000 .000} \times 100 \% \\
& =16,26 \%
\end{aligned}
$$


2. Tahun 2018

$$
\begin{aligned}
\mathrm{ROE} & =\frac{670.644 .872}{4.754 .000 .000} \times 100 \% \\
& =14,10 \%
\end{aligned}
$$

3. Tahun 2019

$$
\begin{aligned}
\text { ROE } & =\frac{649.184 .546}{5.177 .000 .000} \times 100 \% \\
& =12,53 \%
\end{aligned}
$$

Maka dapat disimpulkan bahwa ROE PT. BPR Batang Kapas tahun 2017 sebesar $16.26 \%$ dan tahun 2018 sebesar $14.10 \%$ dan tahun 2019 sebesar $12.53 \%$, Berdasarkan perhitungan tersebut ROE bank ini mengalami penurun. Penilaian persentase Return On Asset nya kurang baik, bank tidak efektif dan tidak efesien serta tidak memanfaatkan modal yang dimilikinya untuk memperoleh keuntungan.

3. Analisi Rasio Beban Operasional dan pendapatan Operasional

(Wirawan, 2016) menjelaskan bahwa BOPO merupakan perbandingan antara biaya operasional dengan pendapatan operasional dalam mengukur tingkat efisiensi dan kemampuan bank dalam melakukan kegiatan operasinya. Beban operasional digunakan untuk mengukur tingkat efisiensi dan kemampuan bank dalam melakukan kegiatan operasionalnya. Matriks penilaian tingkat rasio BOPO menurut Bank Indonesia (Surat Edaran Bank Indonesia, 2004) sebagai berikut :

BOPO $\leq 83 \%$ Sangat baik

$83 \%<\mathrm{BOPO} \leq 85 \%$ Baik

$85 \%<$ BOPO $\leq 87 \%$ Cukup

$87 \%<$ BOPO $\leq 89 \%$ Tidak baik

$\mathrm{BOPO} \geq 89 \%$ Sangat tidak baik

Berdasarkan data yang diperoleh Beban Operasional terhadap Pendapatan Operasional Bank (BOPO) PT. BPR Batang Kapas ditunjukkan pada tabel dibawah in: 
Tabel 4

Perhitungan Beban Operasional PT. BPR Batang Kapas

Tahun 2017-2019 (Dalam Rupiah)

\begin{tabular}{lccc}
\hline \multicolumn{1}{c}{ Komponen } & Tahun 2017 & Tahun 2018 & Tahun 2019 \\
\hline 1. Bopo & & & \\
a. Beban Operasional & & & \\
- Beban bunga & 1.619 .889 .688 & 1.653 .641 .247 & 1.781 .695 .362 \\
- Beban Adm dan umum & 2.345 .035 .467 & 2.305 .324 .924 & 2.633 .570 .066 \\
- Beban pemasaran & 27.641 .000 & 26.372 .750 & 29.732 .209 \\
- Penyisihan aktiva & 40.385 .536 & 157.139 .313 & 173.882 .857 \\
produktif & & & \\
- Beban Operasional & 38.730 .683 & 32.595 .478 & 36.296 .256 \\
lainnya & & & \\
Jumlah Beban Operasional & 4.071 .682 .374 & 4.175 .073 .712 & 4.655 .176 .748 \\
b. Pendapatan Operasional & & & \\
- Bunga & 4.044 .025 .471 & 4.099 .579 .300 & 4.558 .188 .440 \\
- Provisi dan komisi & 301.868 .201 & 281.287 .086 & 370.997 .242 \\
- Pendapatan lainnya & 66.137 .270 & 84.629 .392 & 119.263 .328 \\
Jumlah $\quad$ Pendapatan & 4.783 .915 .970 & 4.899 .310 .576 & 5.414 .570 .917 \\
Operasional & & & \\
\hline Sumber LapDan Keuangan PT. BPR Batang Kapas & & \\
\hline
\end{tabular}

Sumber : Laporan Keuangan PT. BPR Batang Kapas

Total Beban Operasional

Dengan formula : $\mathrm{BOPO}=-\times 100 \%$

Total Pendapatan Operasional

1. Tahun 2017

$$
\begin{aligned}
\mathrm{BOPO} & =\frac{4.071 .682 .374}{4.783 .915 .970} \times 100 \% \\
& =85,11 \%
\end{aligned}
$$

2. Tahun 2018

$$
\begin{aligned}
\mathrm{BOPO} & =\frac{4 \cdot 175 \cdot 073.712}{4.899 \cdot 310.576} \times 100 \% \\
& =85,21 \%
\end{aligned}
$$

3. Tahun 2019

$$
\begin{aligned}
\mathrm{BOPO} & =\frac{4.655 .176 .748}{5.414 .570 .917} \times 100 \% \\
& =85,97 \%
\end{aligned}
$$

Dapat kita simpulkan bahwa BOPO PT. BPR Batang Kapas tahun 2017 sebesar 85.11\%, tahun 2018 sebesar 85.21\% dan tahun 2019 sebesar $85.97 \%$. Dari hasil tersebut dapat ditarik kesimpulan bahwa kinerja Bank ini efesien. Karena persentase BOPO tergolong kedalam kriteria sangat baik penilaian BI. Sebab bank bisa menghasilkan persentase di bawah $83 \%$. Jika persentasi BOPO ini semakin kecil maka bank akan semakin tinggi mendapatkan laba, karena bank bisa 
mengendalikan biaya seefesien mungkin atas operasinal perusahaan yang dilakukan. Jika sebaliknya bank memiliki persentase BOPO yang lebih dari $89 \%$ maka bank dikatakan sangat tidak baik karena banyaknya biaya yang dikeluarkan oleh bank atas operasoinal yang dilakukan. Sehingga keuntungan yang didapatkan oleh bank akan berkurang karena pengeluaran yang banyak tersebut.

4. Rasio Net Profit Margin (NPM)

Net Profit Margin adalah perbandingan antara laba bersih dengan penjualan. Semakin besar NPM, maka kinerja perusahaan akan semakin produktif, sehingga akan meningkatkan kepercayaan investor untuk menanamkan modalnya pada perusahaan tersebut. Rasio ini menunjukkan berapa besar persentase laba bersih yang diperoleh dari setiap penjualan. Semakin besar rasio ini, maka dianggap semakin baik kemampuan perusahaan untuk mendapatkan laba yang tinggi (Aisyah, 2020). Matriks penilaian tingkat rasio NPM menurut Bank Indonesia (Surat Edaran Bank Indonesia, 2004) adalah sebagai berikut :

$\mathrm{NPM} \geq 100 \%$ Sangat baik

$81 \% \leq \mathrm{NPM}<100 \%$ Baik

$66 \% \leq \mathrm{NPM}<81 \%$ Cukup

$51 \% \leq \mathrm{NPM}<66 \%$ Tidak baik

NPM $<51 \%$ Sangat tidak baik

Berdasarkan data yang diperoleh Net Profit Margin PT. BPR Batang Kapas pada periode 2017 sampai 2019 ditunjukkan pada tabel dibawah ini :

Tabel 5

Perhitungan Net Profit Margin PT. BPR Batang Kapas Tahun 2017-2019 (Dalam Rupiah)

\begin{tabular}{lccc}
\hline \multicolumn{1}{c}{ Komponen } & Tahun 2017 & Tahun 2018 & Tahun 2019 \\
\hline $\begin{array}{l}\text { 1. Net Profit Margin } \\
\text { a. Laba bersih setelah }\end{array}$ & 659.699 .437 & 670.644 .872 & 649.184 .546 \\
pajak & & & \\
b. Pendapatan operasional & & & \\
- Bunga & 4.044 .025 .471 & 4.099 .579 .300 & 4.558 .188 .440 \\
- Provisi dan Komisi & 301.868 .201 & 281.287 .086 & 370.997 .242 \\
- pendapatan lainnya & 66.137 .270 & 84.629 .392 & 119.263 .328 \\
Jumlah Pendapatan & 4.783 .915 .970 & 4.899 .310 .576 & 5.414 .570 .917 \\
Operasional & & & \\
\hline
\end{tabular}

Sumber : Laporan Keuangan PT. BPR Batang Kapas

Laba Bersih Setelah Pajak

Dengan formula : NPM $=\longrightarrow \times 100 \%$

Total Pendapatan Operasional

1. Tahun 2017

$$
\begin{aligned}
\mathrm{NPM} & =\frac{659.699 .437}{4.783 .915 .970} \times 100 \% \\
& =13,78
\end{aligned}
$$


2. Tahun 2018

$$
\begin{aligned}
\mathrm{NPM} & =\frac{670.644 .872}{4.899 .310 .576} \times 100 \% \\
& =13,68 \%
\end{aligned}
$$

3. Tahun 2019

$$
\begin{aligned}
\mathrm{NPM} & =\frac{649.184 .546}{5.414 .570 .917} \times 100 \% \\
& =11,98 \%
\end{aligned}
$$

Dapat disimpulkan bahwa NPM PT. BPR Batang Kapas tahun 2017 sebessar 13.78\%, tahun 2018 sebesar 13.68\% dan pada tahun 2019 sebesar $11.98 \%$. Berdasarkan perhitungan tersebut NPM PT. BPR Batang Kapas mengalami penurunan, bahkan ini adalah kondisi yang sangat buruk dalam penilaian kriteria penilaian BI sebab kurang dari 51\%, semakin tinggi Net Profit Margin maka semakin baik ratio ini bagi perusahaan dalam memperoleh laba yang dapat dijadikan ukuran representatif. Keuntungan yang diperoleh tersebut juga harus dibandingkan dengan besarnya jumlah dana untuk mendapatkan laba tersebut Artinya kemampuan bank dalam memperoleh laba dengan pengelolaan biaya operasional bank harus diperhatikan supaya tidak berdampak buruk.

\section{SIMPULAN}

Gambaran tingkat profitabilitas PT. BPR Batang Kapas selama periode tahun 2017 sampai 2019 sebagai berikut :

Tabel 6

perbandingan Rasio Profitabilitas PT. BPR Batang Kapas tahun 2017 - 2019

\begin{tabular}{cccc}
\hline Rasio & Tahun 2017 & Tahun 2018 & Tahun 2019 \\
\hline Return On Assets & $2,17 \%$ & $2,04 \%$ & $1,19 \%$ \\
Return On Equity & $16,26 \%$ & $14,10 \%$ & $12,53 \%$ \\
Biaya Operasional & $85,11 \%$ & $85,21 \%$ & $85,97 \%$ \\
Net Profit Margin & $13,78 \%$ & $13,68 \%$ & $11,98 \%$ \\
\hline
\end{tabular}

Sumber : Laporan Keuangan PT. BPR Batang Kapas

1. Dari rasio ROA PT. BPR Batang Kapas pada tahun 2017 nilai ROA nya sebesar 2,17\%, tahun 2018 nilai ROA nya sebesar 2,04\% dan tahun 2019 nilai ROA nya sebesar $1,19 \%$. Jadi dari tahun 2017 sampai pada tahun 2019 mengalami penurunan. Sehingga bank belum mampu menghasilkan laba bersih sebelum pajak karena ROA nya mengalami penurunan. Tingkat kesehatan bank nya tetap baik, sehingga bank dapat beroperasi dengan efektif dan efisien dalam menggunakan atau memanfaatkan aktiva yang dimilikinya dalam menghasilkan keuntungan.

2. Dari rasio ROE PT. BPR Batang Kapas pada tahun 2017 nilai ROE nya sebesar 16,26\%, tahun 2018 nilai ROE nya sebesar $14,10 \%$ dan pada tahun 
2019 nilai ROE nya sebesar 12,53\% yaitu mengalami penurunan. Tingkat kesehatan bank nya cukup, sehingga kemampuan bank dalam mencapai laba bersih kurang baik.

3. Dari rasio BOPO PT. BPR Batang Kapas pada tahun 2017 nilai BOPO nya sebesar 85,11\%, tahun 2018 nilai BOPO nya sebesar 85,21\% dan pada tahun 2019 nilai BOPO sebesar 85,97\% emngalami kenaikan pada tahun 2019 dan tingkat kesehatan bank nya cukup. Tapi menurut standar BI BOPO masih dalam kategori baik.

4. Dari rasio NPM PT. BPR Batang Kapas pada tahun 2017 nilai NPM sebesar 13,78\%, tahun 2018 nilai NPM nya sebesar 13,68\% dan pada tahun 2019 nilai NPM nya sebesar 11,98\%. Jadi pada tahun 2017 sampai 2019 mengalami penurunan. Sehingga bank belum mampu menghasilkan laba bersih setelah pajak karena NPM nya mengalami penurunan.

\section{UCAPAN TERIMA KASIH}

Penulis mengucapkan terima kasijh kepada PT. BPR Batang Kapas yang telah mengizinkan dan membantu penulis dalam memperoleh informasi, Serta semua pihak yang telah membantu dalam penyelesaian artikel ini

\section{DAFTAR PUSTAKA}

Afriyeni, A., \& Fernos, J. (2018). Analisis Faktor-Faktor Penentu Kinerja Profitabilitas Bank Perkreditan Rakyat (Bpr) Konvensional Di Sumatera Barat. Jurnal Benefita, 3(3), 325. https://doi.org/10.22216/jbe.v3i3.3623

Kasmir, D. (2014). Bank Dan Lembaga Keuangan Lainnya. Edisi Revisi 2014 PT Raja Grafindo Persada Jakarta.

Marlius, D., \& Pebriyana, S. (2020). Analisis Rasio Profitabilitas Pada Pt. Bank Pembangunan Daerah Sumatera Barat Cabang Utama Padang. https://doi.org/10.31219/osf.io/7gnd5

Marlius, D., \& Ilhami, S. (2020). Analisis Ratio Profitabilitas Pada Pt. Bank Perkreditan Rakyat Jorong Kampung Tangah Pariaman. https://doi.org/10.31219/osf.io/f9gau

Marlius, D., \& Mutia, M. (2020). Analisis Rasio Profitabilitas Pada Pt. Bank Pembangunan Daerah Sumatera Barat Cabang Pembantu Rsup Dr. M. Djamil Padang. https://doi.org/10.31219/osf.io/9nrc7Oktaviani, D. P. I. (2015). Pengaruh Return On Asset (ROA), Return On Equity (ROE), Net Profit Margin (NPM) dan Debt To Equity Ratio (DER) Terhadap harga saham.

Mustika, S., \& Marlius, D. (2019). Analisa Tingkat Kesehatan Keuangan PT. Bank Perkreditan Rakyat (BPR) Batang Palangki. https://doi.org/10.31219/osf.io/wupyh

PSAK No. 1. (2009). Pernyataan Standar Akuntansi Keuangan 1 (Revisi 2009) (Statement Of Financial Accounting Standards). Ikatan Akuntansi Indonesia.

Putri, D. M., \& Marlius, D. (2020). Analisis Rasio Profitabilitas Pada Pt. Bank Perkreditan Rakyat Lugas Dana Mandiri Padang. https://doi.org/10.31219/osf.io/kaw2e 
Putri, Y. A., \& Marlius, D. (2018). Analisis Tingkat Kesehatan Bank Pada PT. Bank Perkreditan Rakyat (BPR) Jorong Kampuang Tangah Pariaman Cabang Padang. https://doi.org/10.31227/osf.io/r98pv

Sutrisno. (2014). Pengaruh Profitabilitas Terhadap Kebijakan Dividen dan Nilai Perusahaan. 10(2), 32-48.

Sari, Y. P., \& Marlius, D. (2019). Analisis Rasio Profitabilitas Pada PT. Bank Negara Indonesia Syariah. https://doi.org/10.31219/osf.io/94bwq

Surat Edaran Bank Indonesia. (2004). Surat Edaran Bank Indonesia. CWL Publishing Enterprises, Inc., Madison, 1-11.

Vernida, M., \& Marlius, D. (2020). Analisis Rasio Profitabilitas Pada Pt. Bank Perkreditan Rakyat Cempaka Mitra Nagari Padang. https://doi.org/10.31219/osf.io/6usfx

Wirawan, A. (2016). Pengaruh ROA, ROE, dan BOPO Terhadap Tingkat Bagi Hasil Deposito Mudharabah Pada Bank Umum Syariah. 